\title{
Stanfield's Concepts of Social and Political Economy: Introduction to the Special Issue
}

Phillip Anthony O’Hara

Global Political Economy Research Unit, Economics Department, Curtin University, Perth, Australia.philohara@yahoo.com

\begin{abstract}
This introduction to the special issue of the Forum for Social Economics discusses the conceptual advances made by James Ronald Stanfield that are critical to the future of social and political economy. We introduce the papers by Stanfield and O'Hara, which provide an overview of the conceptual advances. We then introduce the concepts of historical specificity, as well as policy and governance, and how they are need to be seen as interlinked into the cultural and institutional environment. The concept of the disembedded economy is then analysed and related to the papers by Kunibert Raffer and Doug Brown. This is followed by the concept of the economic surplus, and the notion of the surplus as a fund for social change, which is discussed by Mary Wrenn in her paper. The concept of reciprocity, nurturance and love is then linked to Edward O’Boyle's paper, which sees close parallels between his own personalist economics and Stanfield's inquiry. The final concept to be introduced is Stanfield's notion of institutional change and transformation, which John Marangos scrutinises in the rapid changes happening in Central and Eastern Europe. The future of social and political economy is then explored relative to the need to understand and change the world for the better through analysing the core problems that successively emerge through historical time.
\end{abstract}

Keywords: Stanfield • Concepts • Social Economy $•$ Political Economy

\section{Introduction}

The purpose of this special issue of the Forum for Social Economics is to examine in some depth the concepts embedded in the works of James Ronald Stanfield. Special reference is given to the nature and degree to which Stanfield developed and enriched concepts, which is important for the development of social and political economy. Only recently have scholars begun to realise the crucial importance of conceptual development in alternative economics. By the 1960s the various movements of heterodoxy started to re-emerge, and after forty years of scholarly endeavour we would expect to have some degree of conceptual development to enhance its scholarly endeavours into the future. This special issue centres on the extent to which such conceptualisation has been successfully developed by one of the great fathers of social economics, Stanfield himself.

Nothing is more important to scholarly inquiry than conceptual development. Such practical and action-oriented schools of thought-such as institutional, social, feminist, neoMarxian and post-Keynesian-depend on conceptual evolution. This is true since action has to be guided by principles, in the last analysis, and if these principles fail to emerge then nothing of durable substance is forthcoming to guide action and policy. Hence the extent to which many writers have been actively scrutinising this question, spurred into action by the works of 
Stanfield. Without Stanfield most contributors to this volume would have been left in the dark about the road ahead for conceptual inquiry.

I saw the Stanfield festschrift and this current volume as an opportunity to gather scholars together to analyse the extent to which Stanfield had stimulated the emergence of principles of social and political economy in his active and continuing scholarly work. We had a successful conference in early 2006 in Boston at the Hyatt Hotel, where eight presenters started the process of developing this special issue of the Forum, and dozens of scholars debated and celebrated the contribution of Stanfield to social and political economy.

The conference was also a good opportunity for critically examining our papers on Stanfield, and providing a foundation for further analysis, reflection and rewriting. During 2007 and 2008 these papers were refereed and rewritten, while during 2008 and 2009 final versions emerged. As the organiser of the process, and editor of this special issue, I sought to direct inquiry into concepts and principles of a durable nature that Stanfield stimulated. This theoretical edifice is dialectically linked with evidence, institutional situating and cultural embeddeding. Some concepts may have a longer historical relevance than others, while many of the concepts are specific to a social formation, or at least the application of some concepts has been historically embedded more than other concepts.

\section{Concepts Analysed in the Papers}

The first two papers in this special issue, by Stanfield and O'Hara, look at the big picture in terms of the major concepts that emerge from Stanfield's works. The first concept, historical specificity, tells us that everything needs to be situated in a specific historical juncture, and that only if this is done can the principles make any situational sense. For this reason, therefore, Stanfield in the first paper situates the major concepts in an historical context. O'Hara deals with historical specificity mainly through embedding his paper in the life of Stanfield himself, in the institutional-building that he contributed to, especially through the dozens of PhD students that he helped to foster and nurture, and the numerous books and articles he wrote.

The second concept is that of policy and governance. What is the nature of community, state, family and corporate impacts on the general social order. This broad notion of governance recognises that policy is endogenous to the institutional environment and is not separated into specific institutions as a general process. Hence, when Stanfield analyses the role of the Great Capitalist Restoration (GCR) he situates it within a very broad framework of how it impacts on all the major institutions along with individuals. While neoliberalism has often been linked to state action, GCR is a systemic process whereby certain motives of private ownership, profit, enterprise and individualism has been affecting the lives of most people in the world over the past thirty years. The most obvious consequence has been the generation of the great global subprime crisis of 2008-2009, which may help to instil a social democratic trend of governance into the immediate future. All contributors to this issue deal with issues of governance.

The third concept Stanfield contributed to is that of the disembedded economy. The papers by Kunibert Raffer and Doug Brown pay special attention to this concept developed by Karl Polanyi, and they also illustrate how Stanfield directed the concept in his own way (Stanfield 1986). Raffer examines the historical significance of the disembedded economy, in terms of how recent neoliberal trends represent (to some degree) a return to a previous era when markets were given more freedom. Special reference is given to how this manifests itself in notions of freedom, capital movements, anti-democratic trends, and removing social protection. Further work is done analysing trade and pensions. Brown explores this concept in relation to the double movement, especially market freedom versus human security and assured versus earned security. He then examines the significance of the double movement for actual and potential protective responses of the recent past, present and future.

The fourth concept is that of the economic surplus. This idea is so fundamental, yet surprisingly one that has not been too conspicuous in social and political economy in recent 
years. Perhaps one reason for this is the confusion between the notions of 'surplus value' and 'economic surplus', and how most scholars have kept to the former use of the general notion of surplus. The time is ripe for reconciliation between these concepts. Stanfield has contributed in many ways to the economic surplus ever since the time of his $\mathrm{PhD}$ (Stanfield 1973). One of the main ways he sought to advance conceptual inquiry was to posit the notion of the economic surplus as a fund for social change. Mary Wrenn develops this point in her paper, which elaborates on the ways in which the surplus has been distributed more recently, and then to detail how the fund for social change can be developed. Special reference is given to public infrastructure, transport, education, health, environmental solutions and alternative social projects.

The fifth concept includes the complex relationship between reciprocity, nurturance and love. Stanfield sought to promote issues related to the quality of live, communication and sociality (Stanfield 1979). He recognised the need for human expression as well as sustainable linkages between humanity and the ecological environment. This complex interplay of how human beings treat each other and the ecological environment is really the core of Stanfield's concerns. Edward J. O’Boyle in his paper sees close links between Stanfield's view of the world and his own perspective of personalist social economics. O'Boyle and Stanfield both seek to balance individual and social concerns, social and environment issues, and material and immaterial elements. What this amounts to is a shift from looking at individuals to examining persons, and how the quality of the human and ecological experience can be enhanced.

The sixth concept is that of institutional change and transformation, which is the core of Stanfield's work and also that of social and institutional economics. He emphasises in much of his work the importance of the provisioning process, since before profit and accumulation can be stimulated one must consider the needs of social and ecological reproduction. Protective institutional structures utilise considerable resources, and need to be a top priority for governance practitioners of all persuasions. Public goods or system functions such as basic needs, public infrastructure, community participation, and environmental preservation are thus pre-requisites for long term instrumental change and metamorphosis (a la Marc Tool and Dale Bush). John Marangos in his paper considers these factors in the process of social change and transition in Central and Eastern Europe. Special reference is given to the need for minimal dislocation of institutions and the maintenance of some degree of continuity of the life process for the people of these countries. This was at odds with the experience of many of them and provides a critical policy principle for action into the future.

\section{The Future of Social and Political Economy}

The future of social and political economy depends upon developing and maintaining a durable conceptual edifice which can help explain the major problems of the world. In this connection, the work of James Ronald Stanfield and his followers can perform a fruitful role. Stanfield sought, above all else, to generate conceptual clarity, evolution and development for future generations of scholars, policy-analysts and activists to use for understanding and changing the world for the better. He sought conceptual development in his published works, through his considerable efforts in associations of heterodox economists and with his numerous $\mathrm{PhD}$ students. Generations of scholars, policy analysts and activists have been utilizing these concepts, which will likely make a sustained contribution to the quality of life of humanity and other species on planet Earth.

Stanfield's contributions to conceptual clarity and development are especially useful for comprehending the numerous crises that have emanated from the inability of capital and the state to provide sufficiently for the long-term reproduction process. For instance, Stanfield's concepts are useful for policies relevant to the subprime crisis, the climate change problem, and the global and regional process of uneven development. In examining these topics the works of Stanfield and the radical institutionalists are very useful (Brown 1988; Dugger 1989; Stanfield 1995; 
O'Hara 2010); including, for instance, the concept of the disembedded economy. One aspect of this is the notion of fictitious commodities, namely, that money, land and labor are different from normal commodities and need to be treated mainly as public goods or system functions.

The subprime crisis is a complex phenomena but essentially concerns the dominance of finance over industry and the inability to suitably solve the problem of fictitious commodities (money and credit). In a similar fashion, the climate change problem is mainly related to the inability to solve the contradiction of profit and the environment, again related to fictitious commodities (land, water and air). The anomaly of global and regional uneven development is a manifestation of the contradiction between hegemonic nations and those of much less political and economic power; which is closely related to the contradiction between different nation states and the inability to solve problems related to fictitious commodity reproduction on the global scale (labor, land and money). These problems thus concern the social and ecological reproduction needs of the planet (the protective response; Stanfield and Carroll 2009), which need to be provided by the community for the system to survive in the long-term.

In conclusion, I wish to thank members of the Association for Social Economics, and the editor of this journal, John Marangos, for their efforts in stimulating the tradition of social economics, including Stanfield's concepts. I thank contributors to this special issue for their warmth, generosity and scholarly expertise in illustrating the conceptual importance of James Ronald Stanfield for understanding critical world problems. I also wish, above all, to thank Ron Stanfield for his friendship, academic stimulation and sociality over several decades. I hope you enjoy this special issue, Ron!

\section{References}

Brown, D.M. (1988) Towards a radical democracy: The political economy of the Budapest school. London: Unwin Hyman.

Dugger, W.D. (1989) Radical institutionalism: Contemporary voices. New York: Greenwood Press.

O’Hara, P.A. (2010) Principles of political economy-Applied to contemporary world problems. GPERU: Perth, Aust.

Stanfield, J.R.. (1973) The economic surplus and neo-Marxism. Lexington, Massachusetts; London, UK: Lexington Books.

Stanfield, J.R.. (1979) Economic thought and social change. Carbondale \& Edwardsville, US and London \& Amsterdam: Southern Illinois University Press and Feffer and Simons Inc.

Stanfield, J.R.. (1986) The economic thought of Karl Polanyi: Lives and livelihood. New York; St Martins Press.

Stanfield, J.R. (1995) Economics, power and culture: Essays in the development of radical institutionism. New York: St. Martin’s Press.

Stanfield, J.R. \& Carroll, M. (2009) The social economics of neoliberalism globalization. Forum for Social Economics. 38(1): 1-18.

Phillip Anthony O'Hara is Professor of Global Political Economy and Governance at the Global Political Economy Research Unit, Economics Department, Curtin University, Perth, Australia. He won the 2002 Gunnar Myrdal Award from the European Association for Evolutionary Political Economy, and the 1998 Clarence Ayres Award from the Association for Evolutionary Economics (AFEE), based in the USA. He is on the editorial boards of the Journal of Economic Issues; the Review of Social Economy; also Intervention: European Journal of Economics and Economic Policy, and the International Journal of Pluralism and Economics Education. He works in the areas of principles of political economy, social structures of accumulation, policy and governance, and political economy biography. His latest book is the 
International Encyclopedia of Public Policy (4 vols):

http://pohara.homestead.com/encyclopedia/volume-1.pdf Email: philohara@yahoo.com 